\title{
ANALYSIS OF THE DEGREE OF GRASSLAND DEGRADATION USING REMOTE SENSING
}

\author{
Jaíza Santos Motta \\ Universidade Federal de Mato Grosso do Sul - UFMS \\ Faculdade de Engenharia, Arquitetura e Urbanismo e Geografia, Campo Grande, MS, Brasil \\ ea.jsmotta@gmail.com
}

César Claudio Cáceres Encina

Universidade Federal de Mato Grosso do Sul - UFMS

Faculdade de Engenharia, Arquitetura e Urbanismo e Geografia, Campo Grande, MS, Brasil ccaceres.encina@gmail.com

Eliane Guaraldo

Universidade Federal de Mato Grosso do Sul - UFMS

Faculdade de Engenharia, Arquitetura e Urbanismo e Geografia, Campo Grande, MS, Brasil eliane.guaraldo@gmail.com

\begin{abstract}
Ariadne Barbosa Gonçalves
Universidade Federal de Mato Grosso do Sul - UFMS

Faculdade de Engenharia, Arquitetura e Urbanismo e Geografia, Campo Grande, MS, Brasil ariadne.gon@gmail.com

Roberto Macedo Gamarra

Universidade Federal de Mato Grosso do Sul - UFMS

Faculdade de Engenharia, Arquitetura e Urbanismo e Geografia, Campo Grande, MS, Brasil rmgamarra@gmail.com
\end{abstract}

Antonio Conceição Paranhos Filho Universidade Federal de Mato Grosso do Sul - UFMS Faculdade de Engenharia, Arquitetura e Urbanismo e Geografia, Campo Grande, MS, Brasil toniparanhos@gmail.com

\begin{abstract}
The objective of this study is to adapt the calculations of the Pasture Degradation Index (GDI) to the Brazilian savannah using medium spatial resolution satellite image for the dry season. Vegetation cover is the main evaluation parameter used to calculate the GDI. The extreme ranges of the grazing class were determined by the NDVI histogram of a single date. Pasture cover was distinguished into five classes called Vegetable Pasture Cover (GVC), derived from NDVI and compared with five other classes derived from field photographs, named Green Coverage Percentage (GCP). The similarity between GVC and GVP demonstrated that GVC can be used to classify pasture cover. As a product of GVC, GDI was obtained. The GDI showed that pasture degradation in Paraíso das Águas is very serious. Extremely severe and Severe degradation occupy $9.28 \%$ and $25.22 \%$ of the study area, moderate and light degradation of pasture occupy $8.29 \%$ and $4.50 \%$, respectively, and the non-degradation area covers $1.43 \%$ of pastures. The results suggest the possibility of applying the GDI, originally developed for natural fields and multitemporal remote sensing data, to evaluate the conditions of the tropical savanna planted fields by means of a unique image.
\end{abstract}

Keywords: Grassland Degradation Index. Geotechnologies. Cerrado. Landsat 8.

\section{ANÁLISE DO GRAU DE DEGRADAÇÃO DE PASTAGENS USANDO O SENSORIAMENTO REMOTO}

\section{RESUMO}

O objetivo deste estudo é adaptar os cálculos do Índice de Degradação de Pastagens (GDI) à savana brasileira usando imagem de satélite de média resolução espacial para estação 

Conceição Paranhos Filho

\begin{abstract}
seca. A cobertura vegetal é o principal parâmetro de avaliação usado para calcular o GDI. Os intervalos extremos da classe de pastagem foram determinados pelo histograma do NDVI de uma única data. A cobertura de pastagem foi distinguida em cinco classes denominadas Cobertura Vegetal de Pastagem (GVC), derivada do NDVI e comparada com outras cinco classes derivadas de fotografias de campo, nomeadas de Porcentagem de Coberta Verde (GCP). A semelhança entre a GVC e a GVP demonstrou que a GVC pode ser usada para classificar a cobertura de pastagem. Como produto da GVC, foi obtido o GDI. O GDI demonstrou que a degradação de pastagem em Paraíso das Águas é muito séria. Degradação extremamente severa e severa e ocupam 9,28\% e 25,22\%, da área de estudo, degradação de pastagem moderada e leve ocupam $8.29 \%$ e $4,50 \%$, respectivamente, e a área não degradação cobrem $0,9 \%$ das pastagens. Os resultados sugerem a possibilidade de aplicar o GDI, originalmente desenvolvido para campos naturais e dados de sensoriamento remoto multitemporal, para avaliar as condições de pastagens plantadas em savanas tropicais.
\end{abstract}

Palavras-chave: Índice de degradação de pastagens. Geotecnologias. Cerrado. Landsat 8.

\title{
INTRODUCTION
}

Brazil is both the largest consumer and exporter of meat in the world. Approximately 1850 tons of meat are produced for export per year by Brazil (WORLD ATLAS, 2018). The last agricultural census of 2017 revealed that the State of Mato Grosso do Sul had a cattle herd consisting of 19.5 million animals, a total of $13,135,072$ hectares of planted grasslands and $4,430,399$ hectares of natural grasslands (IBGE, 2017).

The viability of grasslands in Brazil is essential for the national and international advance of the livestock sector, and the avoidance of related environmental and economic difficulties. Degraded grassland is characterized as an area with a sharp decrease in agricultural productivity (DIAS FILHO, 2006). In this sense, grassland degradation results from inadequate management and the lack of recovery, which initiate a cycle that includes degradation, growth of invasive plants, and decrease of forage for cattle. Consequently, the stamping of cattle on exposed soil in combination with abiotic factors gives rise to soil erosion.

Half of the Brazilian's grassland areas are in Savanna Biome. However, it is estimated that 32 million hectares, i.e. $60 \%$ of the planted grassland in Brazilian Savanna, of which 6.52 million hectares are in the State of Mato Grosso do Sul, have some level of degradation (EMBRAPA, 2014). Therefore, research on grassland degradation in Brazil and especially in Mato Grosso do Sul, which is the fourth largest beefproducing state (IBGE, 2019), is important for both economic growth and environmental protection.

Investing in more research on grassland degradation assessments should be a priority mainly in cattlebased economies. Monteiro et al. (2018) reported that the analysis of grassland degradation is fast, inexpensive, and its results that are easy to interpret. This was demonstrated by Gao et al., (2006) based on a classification of grassland degradation into five categories that included non-degraded, low degradation, moderate degradation, severe degradation, and extremely severe degradation. Dias Filho (2017), in turn, classified grassland degradation in four levels.

The geotechnologies used in grassland research have grown, as demonstrated by Gao et al. (2006) and Pereira et al. (2018). Gao et al. (2006) used the Normalized Difference Vegetation Index (NDVI) derived from the multi-temporal AVHRR (Advanced Very-High-Resolution Radiometer), SPOT (Satellite Pour I'Observation de la Terre, in French), and MODIS (Moderate Resolution Imaging Spectroradiometer) images from Northern Tibet to estimate the degree of degradation of native grasslands using visible indicators. Pereira et al. (2018) obtained the degree of degradation of grasslands in Cerrado using MODISNDVI images and computer vision techniques to identify the Brazilian states with the highest degree of grassland degradation. Those studies indicate that geotechnologies can be used on a temporal and spatial scale to efficiently and reliably identify degraded grasslands.

Caminhos de Geografia

Uberlândia-MG

v. 22, n. 80

abr./2021

p. 201-219

Página 202 
In the present study, the Grassland Degradation Index (GDI) (GAO et al., 2006) will be adapted to estimate the degree of grassland degradation using a single satellite image of medium spatial resolution during water stress. Since the analysis performed in the study by Gao et al. (2006) required an extensive historical series of images, this adaptation makes the routine of identifying degraded grasslands easier and compatible with the specific conditions of planted grasslands. This study will contribute to research on grassland degradation by identifying their different degrees. Paraíso das Águas was the municipality chosen for the application of the study, but can be extended to another several contexts. The field activities of the research were developed through a cooperation project between with the Federal University of Mato Grosso do Sul and Paraíso das Águas Municipality which allows access to the area.

\section{MATERIALS AND METHODS}

\section{Study Area}

The Municipality of Paraíso das Águas has an area of approximately $5,032 \mathrm{~km}^{2}$ and has a latitude of 7895505.91 South and a longitude of 288180.21 West in the two-dimensional Cartesian UTM (Universal Transverse Mercator) coordinate system. The capital of the State, Campo Grande, is approximately 280 km from Paraíso das Águas (Figure 1).

Figure 1 - Paraíso das Águas (MS): Location of study area. Municipality of Paraíso das Águas covers 5,032 km², approximately. The municipality has a latitude of 7895505.91 South and a longitude of 288180.21 West in the twodimensional Cartesian UTM coordinate system, in the State of Mato Grosso do Sul, Brazil, 2020.
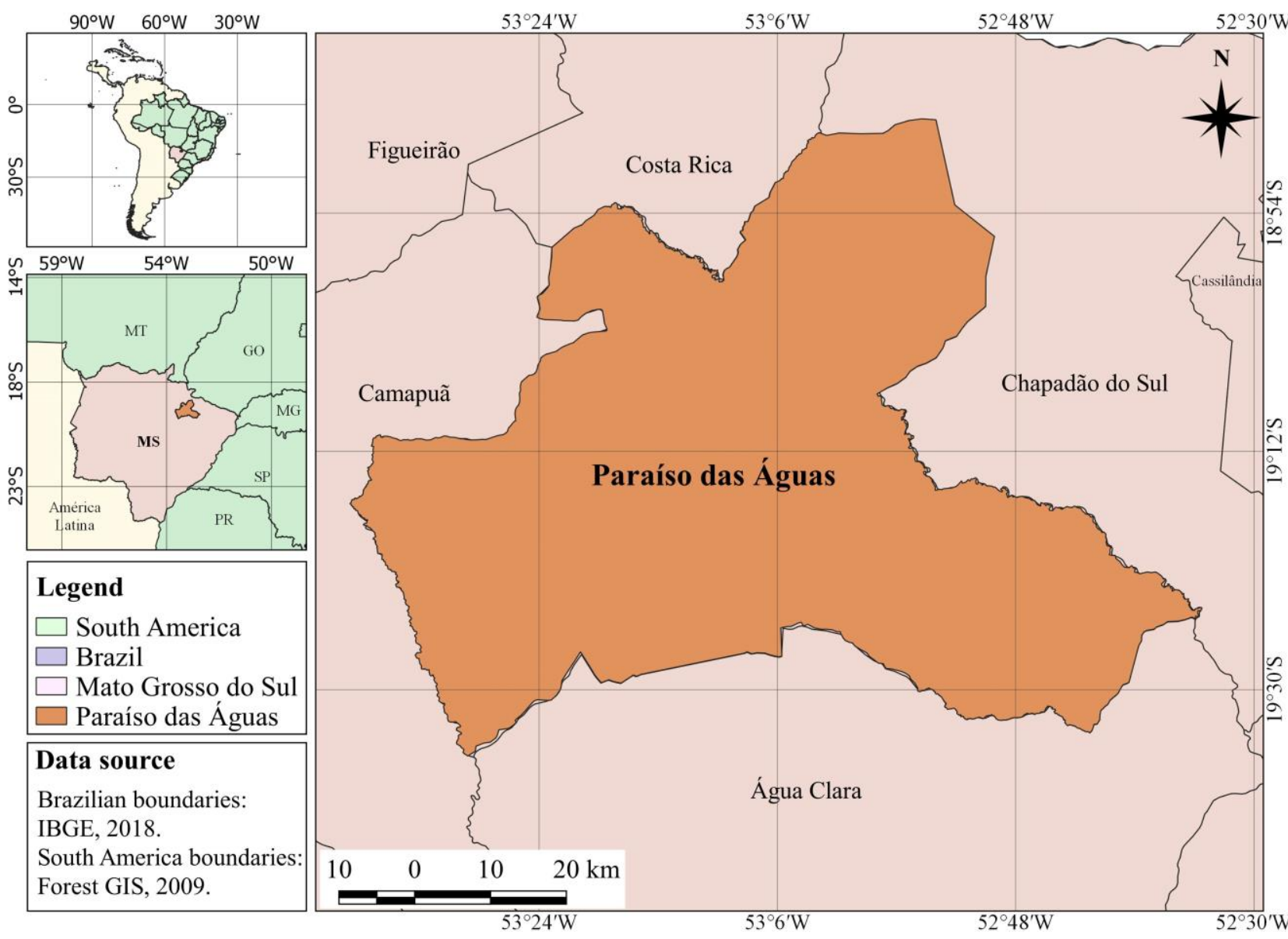

Source - Authors. 

Conceição Paranhos Filho

The study area is situated at northeast of the State of Mato Grosso do Sul, on the Southern Plateau, with vast fields composed of tablelands and hill ranges. The territory is part of the Paraná River Basin (PARAÍSO DAS ÁGUAS, 2017).

Cerrado is the native biome of the municipality, which is considered to be a world biodiversity hotspot. It has a high degree of endemic species and high conversion and degradation of its native habitats (MMA, 2019). Habitat loss occurs due to the replacement of native vegetation by non-indigenous grasslands and agriculture. Currently, the grasslands occupy $2,580 \mathrm{~km}^{2}$ and the dirty fields of Cerrado account for $752 \mathrm{~km}^{2}$ of the Municipality of Paraíso das Águas, based on the classification of Landsat 8 satellite images acquired in 2017 that are presented in this study.

According to Köppen's classification (1918), the climate of Paraíso das Águas is Tropical and Am (Monsonic). The average annual temperature is $23.6^{\circ} \mathrm{C}$ and the average annual precipitation is $1,600 \mathrm{~mm}$. The average altitude of the region is 600 meters.

The estimated population in 2019 was 5,555 inhabitants (IBGE, 2019) and demographical density is approximately 1 inhabitant $/ \mathrm{km}^{2}$. There are not historical census data for Paraíso das Águas - Mato Grosso do Sul. The last demographic census was conducted in 2010 and the region was still a District of the Municipality of Costa Rica. Late in 2013 it became an independent municipality (PARAÍSO DAS ÁGUAS, 2017). Its economy is based on rural activities, such as extensive livestock farming and agriculture.

\section{Data Acquisition and Processing}

This study is based on two data sources. The first are photographic images of the surface of soil or grasslands between August 31 and September 1, 2017 in 40 grasslands in several areas of the Municipality of Paraíso das Águas. The images were acquired using a Sony digital camera, and referenced by the GPS Garmin Monterra GCPS. The second source is an image obtained using the Landsat 8 satellite on 30 August 2017, path/row 224/073, OLI sensor, with Level 2 processing and a spatial resolution of 30 meters. This georeferenced, orthorectified, and atmospherically corrected image was obtained from the website of the United States Geological Survey (USGS, 2017).

Approximately 400 images were captured, 10 images per sampled grassland. These images were taken randomly in each of the 40 grasslands areas under study to create an image bank for the subsequent analysis of the grasslands. Two cameras with different resolutions i.e. an 8-megapixel Garmin Monterra GCPS camera and a 14-megapixel Sony Cyber-Shot model W510, were used to acquire the images. A summary of the cameras used in this study is presented in Table 1. These data were used to measure the Green coverage percentage (GCP) in the field samples.

Table 1 - Paraíso das Águas: Photographic equipment used for the fieldwork the field, 2017.

\begin{tabular}{c|c|c}
\hline Photographic equipment & Grassland sample & Resolution (megapixel) \\
\hline Sony Cyber-Shot & $\begin{array}{c}1,2,4,6,8,12,14,16,18,20,22,23, \\
24,26,28,30,32,33,37 \text { and } 40\end{array}$ & 14 Megapixel \\
& & \\
\hline Garmin Monterra GCPS & $2,3,5,7,9,11,13,15,17,19,21,25$, & \\
& $27,29,31,34,35,36,38$, and 39. & \\
\hline
\end{tabular}



Conceição Paranhos Filho

The satellite image was used in the classification of the land cover, the calculation of the Grassland Vegetation coverage (GVC) percentage, and the determination of the Normalized Difference Vegetation Index (NDVI) (ROUSE et al., 1973). Both information groups were used for the calculation of the Grassland Degradation Index (GDI) (GAO et al., 2006). The GCP and GVC were correlated to quantify the degree of linear association between these two variables of different scales.

The following sections describe the digital processing and the map algebra performed to obtain the GCP, image classification, GVC, NDVI, and GDI.

\section{Estimation of Green coverage percentage in the camera images (GCP)}

The healthy vegetation (greeness) reflects in the green wavelength and absorbs in the red wavelength during photosynthesis. The field pictures were used to quantify the green cells at the software in QGIS 3.4 (QGIS DEVELOPMENT TEAM, 2019), as presented by Equation 1. Then a cell was determined to be green if the value of the ash level of the green band was greater than or equal to the value the ash level of the red band.

$$
g=\text { Green band (Digital Number) } \geq \text { Red band (Digital Number) }
$$

where $\mathrm{g}=$ green cells.

The quantification of vegetation coverage in the camera pictures acquired in the field was performed based on the calculation of the GCP, which was based on the methods adopted in Franco and Rosa (2004) and Santos (2010). GCP was calculated according to Equation 2:

$$
\mathrm{GP}=\frac{\mathrm{Cg} \cdot 100}{\mathrm{Ct}}
$$

where, GCP is the green coverage percentage; $\mathrm{Cg}$ is the number of green cells (pixels) in the image and $\mathrm{Ct}$ is the total number of cells in the image.

These procedures were performed in QGIS 3.4 (QGIS DEVELOPMENT TEAM, 2019), and the results were post-processed in a Microsoft excel spreadsheet.

\section{Satellite image classification}

The Landsat 8 satellite image classification distinguished the patterns of the spatial distribution of vegetation coverage based on automatic object-oriented classification in Trimble's eCognition Developer ${ }^{\circledR}$ 8.9 (TRIMBLE GEOSPATIAL, 2014). The parameters used to classify the image included 1) a scale parameter equal to 100 , and a 2) Composition of Homogeneity Criterion, which defines the value of the parameter for shape as 0.3 , and 0.8 for compactness. The classes defined by sampling were Grassland, Dirty Grassland, and Unclassified. The Grassland area considers dry grassland with a spectral signature different from agricultural areas, because healthy grassland can be confused with agriculture. The grassland area that includes invasion of native plants of Cerrado was classified as dirty grassland. The class of Unclassified encompasses several covers such as cerrado, agriculture, water, and exposed soil.

The class Grassland was used to determinate Grassland Degradation Index (GDI) according to Gao et al. (2006). GDI excludes Dirty Grassland area, as the invasive plants increases the NDVI values and super estimate the grassland health. In addition, Dirty Grassland was analyzed separately, according to Dias et al. (2006), who considers the surface as a level of biological degradation. 


\section{Normalized Difference Vegetation Index (NDVI)}

The Normalized Difference Vegetation Index (NDVI) is a metric for distinguishing between vegetation vigor and for estimating vegetation coverage (ROUSE et al., 1973). The NDVI is calculated based on the difference between the amount of light absorbed and reflected in the wavelength range of red and nearinfrared (ROUSE et al., 1973). The range of the NDVI values varies between -1 and 1 . In general, values close to 1 identify areas with green biomass and values close to 0 represents areas with no vegetation (exposed soil) or low biomass. Values below 0 indicate the presence of water. The NDVI values are calculated as shown in Equation 2:

$$
\text { NDVI }=\frac{(\rho N I R-\rho R)}{(\rho N I R+\rho R)}
$$

where $\rho$ is the band reflectance; NIR is the vegetation reflectance in the near-infrared band and R is the vegetation reflectance in the red band.

After generating the NDVI of the study area, the areas classified as grasslands were extracted. Subsequently, the distribution histogram of the NDVI value of the grasslands was generated based on its frequency. The data analyzed using the histogram served to determine the extremes relative to the limits to be considered in the calculation of the grassland cover (GVC) by remote sensing. This procedure substitutes the multitemporal analysis used by Gao et al. (2006) by a unique satellite image analysis.

\section{Estimation of vegetation coverage in multispectral image}

Vegetation coverage was calculated as follows (PUREVDORJ et al., 1998; LIU, ZHANG \& ZHANG, 2018).

$$
\text { Vc }=\frac{\text { NDVI-NDVIs }}{\text { NDVIV-NDVIs }} \cdot 100 \%
$$

where $\mathrm{Vc}$ is the vegetation coverage, $N D V I$ is value of pixel analyzed, NDVIs is the minimum value of NDVI of land in the study area and the NDVIv is the maximum or average value of NDVI of the pixel values of the grassland class of the area under study.

The value of NDVIs for the grassland was calculated using Equation 4 and the value of NDVIv was obtained as presented in Equation 5. These equations were used because the extreme values relative to the class of grassland that were obtained from the classification of the satellite image inevitably resulted in spurious values (LIU, ZHANG \& ZHANG, 2018). The field data from exposed soil samples and healthy grasslands were used to corroborate these thresholds.

$$
\begin{aligned}
& \text { NDVIs }=\text { NDVImean }-2 . \text { Standard Deviation } \\
& \text { NDVIs }=\text { NDVImean }+2 . \text { Standard Deviation }
\end{aligned}
$$

\section{Statistical analysis between field and satellite images}

Simple linear correlation analysis (Pearson's correlation coefficient) was used to estimate the degree of association between the green coverage percentage (GCP) of the photographic images and the grassland vegetation coverage (GVC) of the satellite image.

\section{Grassland Degradation Index (GDI)}

The Grassland Degradation Index developed by Gao et al. (2006) considers both the principles of Remote Sensing (RS), as well as the characteristics of the RS data and the characteristics of grassland degradation, scientific basis, relative independence, feasibility, comparability, and specificity. 
These authors have established standards related to the definition, degree and the parameters of degradation of natural grassland in China. The reference principles for the assessment of degraded grassland are based on the vegetation characteristics and soil surface conditions, and non-degraded grassland soil using a multi-temporal scale (GAO et al., 2006).

According to Gao et al. (2006), GDI has five degrees of grassland degradation including non-degraded $(N D)$, slightly degraded (SLD), moderately degraded (MD), severely degraded (SED) and extremely degraded (ESD). The parameters, standards, classifications, and scores for monitoring and evaluating grassland degradation are presented in Table 2.

Table 2 - Evaluation index criteria and classification for monitoring of grassland degradation by remote sensing.

\begin{tabular}{l|l|l|l}
\hline $\begin{array}{l}\text { Evaluation } \\
\text { Parameters }\end{array}$ & $\begin{array}{l}\text { Standard monitoring } \\
\text { and evaluation }\end{array}$ & $\begin{array}{c}\text { Degree of } \\
\text { degradation* }\end{array}$ & Grassland degradation classification method \\
& & & \\
\hline $\begin{array}{l}\text { Grassland } \\
\text { Vegetation } \\
\text { Coverage } \\
\text { (GVC) }\end{array}$ & $\begin{array}{l}\text { ND GVC standard, } \\
\text { which is the maximum } \\
\text { value of NDVI of } \\
\text { grassland samples } \\
\text { using extensive } \\
\text { livestock in Paraíso } \\
\text { das Águas. }\end{array}$ & ND (1) & $\begin{array}{l}\text { GVC equal to or greater than } 90 \% \text { of ND GVC } \\
\text { (which is the maximum GVC considered) }\end{array}$ \\
\cline { 3 - 4 } & & SLD (2) & GVC between $75 \%-90 \%$ of ND GVC \\
\cline { 3 - 4 } & & SD (4) & GVC between $60 \%-75 \%$ of ND GVC \\
\cline { 3 - 4 } & ESD (5) & GVC between $30 \%-60 \%$ of ND GVC \\
\hline
\end{tabular}

${ }^{*}$ ND represents Non-Degraded, SLD represents Slightly Degraded, MD represents Moderately Degraded, SD represents Severely Degraded, and ESD represents Extremely Severe Degraded. The number in brackets indicates the degree of grassland degradation.

Source - Adapted from Gao et al. (2006).

Based on the degree of grassland degradation in Paraíso das Águas, GDI was used to express the degree of grassland degradation. The formula for calculating GDI is represented by Equation 6 (GAO et al., 2006):

$$
G D I=\frac{\sum_{\mathrm{i}=1}^{5}\left(\mathrm{D}_{\mathrm{i}} \cdot \mathrm{A}_{\mathrm{i}}\right)}{\mathrm{A}}
$$

where GDI is the grassland degradation index; $\mathrm{Di}$ is the classification score for grassland degradation; $\mathrm{Ai}$ is the distribution area of class $\mathrm{i}\left(\mathrm{km}^{2}\right)$, and $\mathrm{A}$ is the total grassland area in Paraíso das Águas $\left(\mathrm{km}^{2}\right)$.

The standards used to determine the degree of grassland degradation in Paraíso das Águas are shown in Table 3.

Table 3 - Patterns used to determine the degree of grassland degradation.

\section{Grassland degradation index (GDI)}

\begin{tabular}{c|l}
\hline GDI $\leq 1$ & Non-Degraded (ND) \\
\hline $1<\mathrm{GDI} \leq 2$ & Slightly degraded (SLD) \\
\hline $2<\mathrm{GDI} \leq 3$ & Moderately Degraded (MD) \\
\hline $3<\mathrm{GDI} \leq 4$ & Severely Degraded (SD) \\
\hline $\mathrm{GDI}>4$ & Extremely Severe Degraded (ESD) \\
\hline & Source - Gao et al. (2006).
\end{tabular}



Conceição Paranhos Filho

\section{RESULTS AND DISCUSSIONS}

\section{Field data}

The field samples were obtained from degraded grassland areas with exposed soil, invasive plants and were used for the cultivation of grazing seeds with rotational agricultural crops. They represent the actual characteristics of several other rural regions with arable grassland.

In total, forty specimens of grasslands, dirty grasslands, and exposed soil were sampled on-site according to the location and nomenclature are shown in (Figure 2). The geographical boundary of Paraíso das Águas is in the lower right corner of the central figure, and polygon 1 (green) is extended with the location of the samples in the municipality, in the center of Figure 2. Based on this polygon, the images identified from $A$ to $\mathrm{K}$ are enlarged using the 40 grasslands sampled in the field. The geographical limits are on the Landsat 8 satellite image, OLI sensor, path/row 224/073 and false RGB 564 color composition.

Figure 2 - Location of the field samples in Paraíso das Águas. The image chart in the center shows the location of the samples in the Municipality, where polygon number 1 (green) is expanded to indicate the location of the images listed from $A$ to $K$ that cover the forty grasslands under study. The images from $A$ to $K$ have the same spatial scale. The geographical limits are on the Landsat 8 satellite image, OLI sensor, path/row 224/073 and false RGB 564 color composition, where green tones indicate undergrowth and red tones indicate vegetation with higher levels of biomass, 2017.

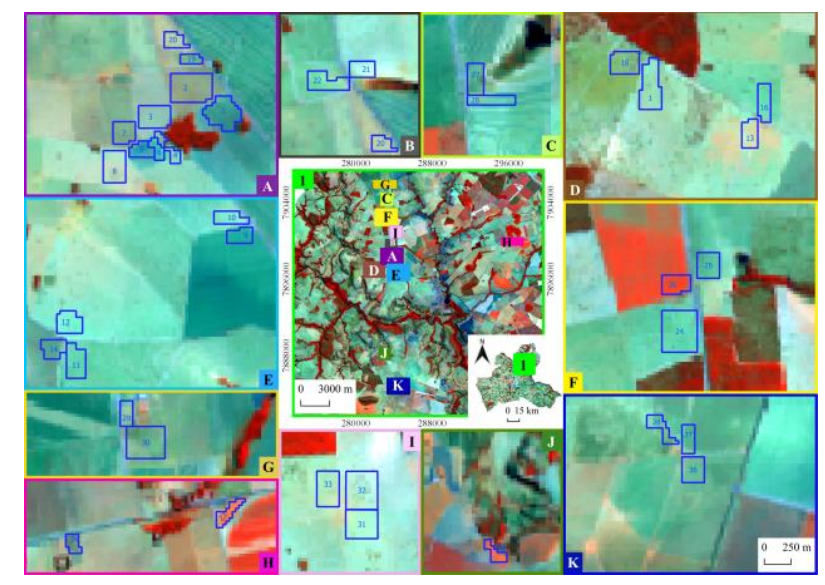

Source - Authors.

Figure 3 shows images of land cover with different degrees of degradation in each of the 40 sampled grasslands (S1 to S40). Grasslands classified as exposed soil are highlighted in red, whereas the grasslands considered as healthy, i.e., without apparent grassland degradation, are highlighted in blue.

The images S5, S6, S9 and S12 presented in Figure 3 are samples classified as exposed soil, because there is little or no vegetation on the surface. The images S3, S26, S35, S39, and S40 are the healthy grasslands samples with conditions controlled by irrigation, fertilization and/or crop rotation of grasslands and agriculture. The other images show grasslands with some level of degradation, probably due to inadequate management reinforced by water stress.

\section{Green coverage percentage of field samples (GCP)}

The results of the Green Coverage Percentage (GCP) are shown in Figure 4, in which the white color represents the "green" portion and the black color represents the "non-green" portion of the field samples. 
The code in the lower-left corner represents the grassland sample where the photographic images were acquired. The photographic images shown below are the same as those shown in Figure 3. It is worth mentioning that all the images obtained in the field underwent this process to generate the average GCP of the grasslands. It is also important to observe that GCP considers the shadow to be a non-green cell, even for healthy vegetation.

The images of the S5, S6, S9, and S12 grasslands presented in Figure 4 corroborate the visual analysis of Figure 3, since most of the cells represented in black in the images generated by the GCP are "non-green" cells. The images of the S23, S26, S35, S39, and S40 grasslands show that these grasslands are healthy, since most of the cells are represented in white and belong to the "green" class. The other GCP show grasslands with some level of degradation.

Figure 3 - Paraíso das Águas (MS): Images of the 40 grassland samples that were investigated. The names S1 to S40 represent the grasslands where these images were taken. The nomenclatures highlighted in red represent grasslands with exposed soil and those highlighted in blue represent healthy grasslands. These images were obtained using a 14megapixel Cyber-Shot camera and an 8-megapixel Garmin Monterra GCPS camera, 2017.

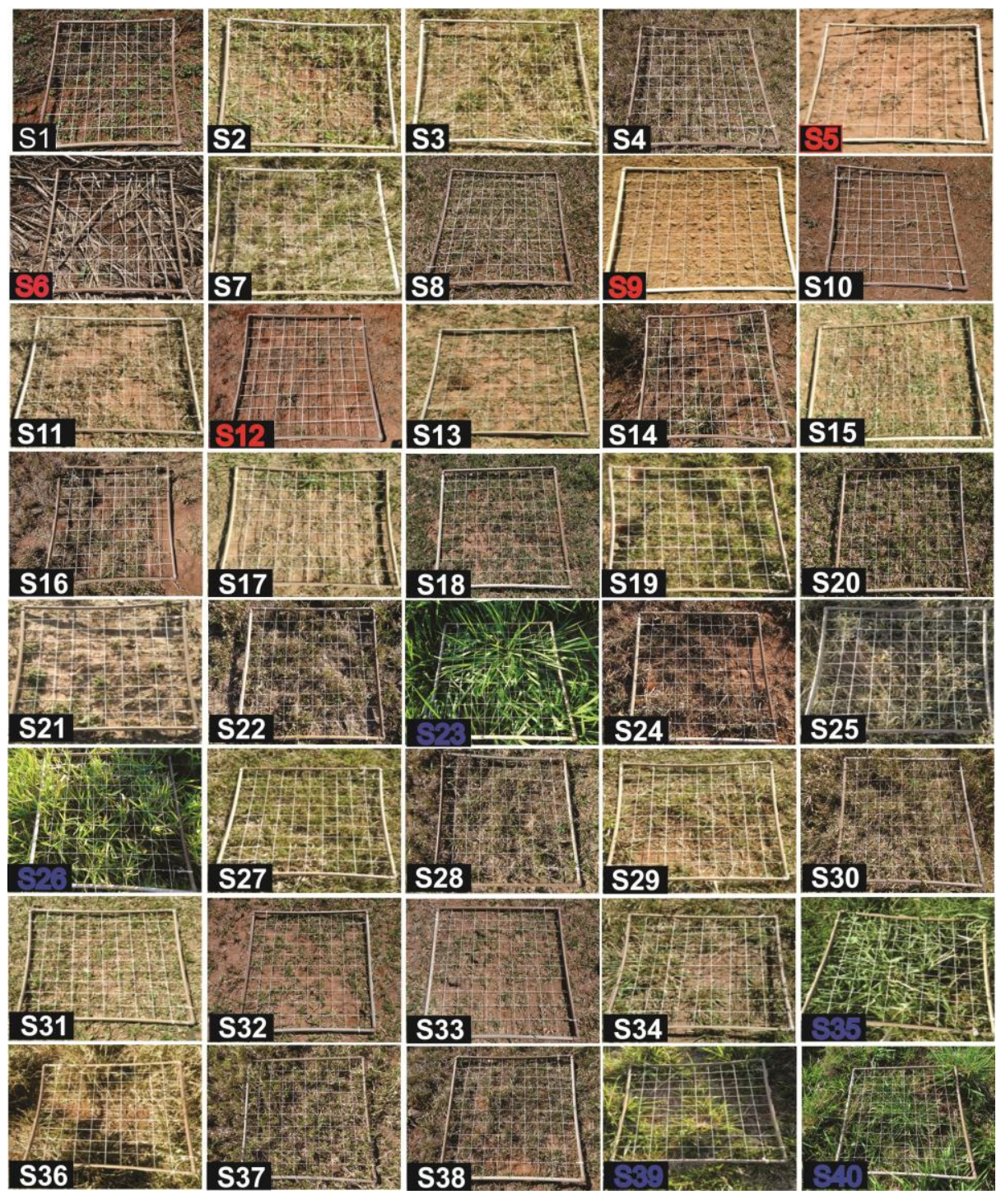

Source - Authors. 
Figure 4 - Paraíso das Águas (MS): Green coverage percentage (GCP) derived from images obtained from the 40 grasslands under study. White color represents the class named "Green". The class "Non-Green" is represented in

black. The nomenclature refers to the grasslands where these images were acquired. The nomenclatures highlighted in red represent grasslands with exposed soil whereas those highlighted in blue represent grasslands with healthy grasslands. The data were obtained using Sony camera and Garmin Monterra GCPS, 2017, both available in Geoprocessing and Environmental Applications Laboratory, at the Federal University of Mato Grosso do Sul.
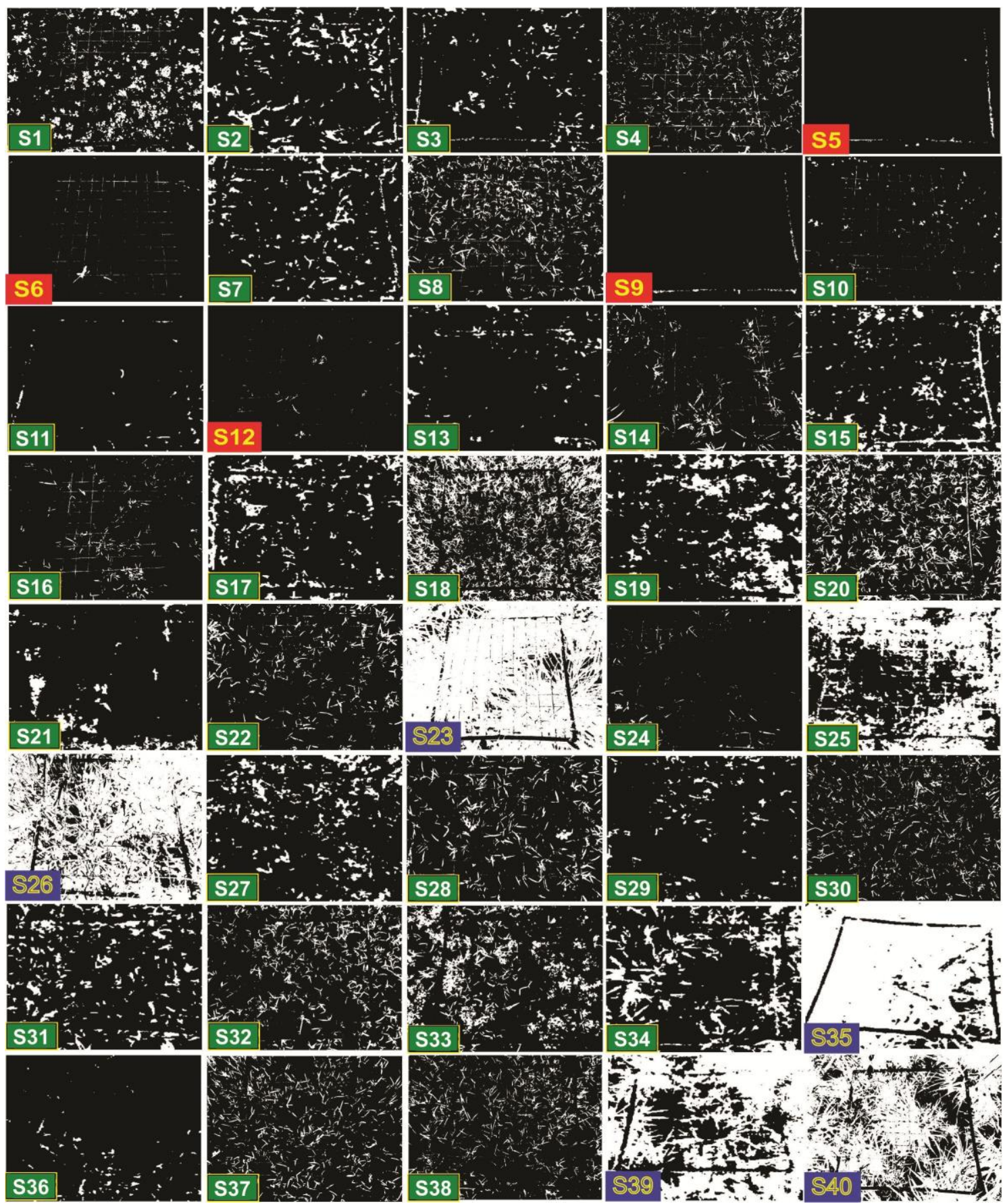

Source - Authors.

The average of the GCP based on the estimation of the green coverage of all the filed pictures in Figure 5 . The GCP shows that the exposed soil grasslands (S5, S6, S9, and S12) and healthy grasslands (S23, S26, S35, S39, and S40) have minimum and maximum values among the samples, as observed in the images. 
Figure 5 - Paraíso das Águas (MS): Graph of the green coverage percentage per grassland plot derived from field images, 2017.

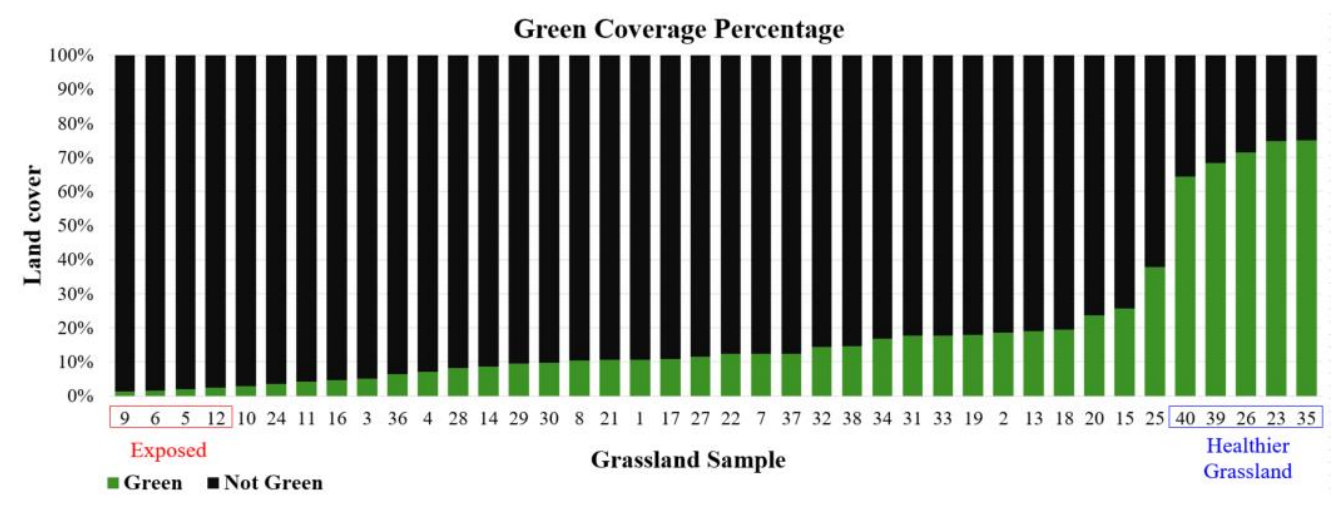

Source - Authors.

\section{Land cover classification}

The classification of land cover in the Municipality of Paraíso das Águas shows that $51 \%\left(2,580 \mathrm{~km}^{2}\right)$ of the total surface of the municipality is dominated by grassland; dirty grassland covers approximately $15 \%$ (752 $\mathrm{km}^{2}$ ), and the others $34 \%$ including cerrado, cerradão, agriculture, and exposed soil are grouped in the class "unclassified". The classification derived from the Landsat 8 satellite image is shown in Figure 6.

Figure 6 - Paraíso das Águas (MS): The grassland areas are represented in green and the dirty grassland areas are represented in ochre, covering $51 \%$ and $15 \%$ of the $5,032 \mathrm{~km}^{2}$ of the study area, respectively. The other land cover areas (beige) belong to the class of "Unclassified" and correspond to 34\% surface, 2017.
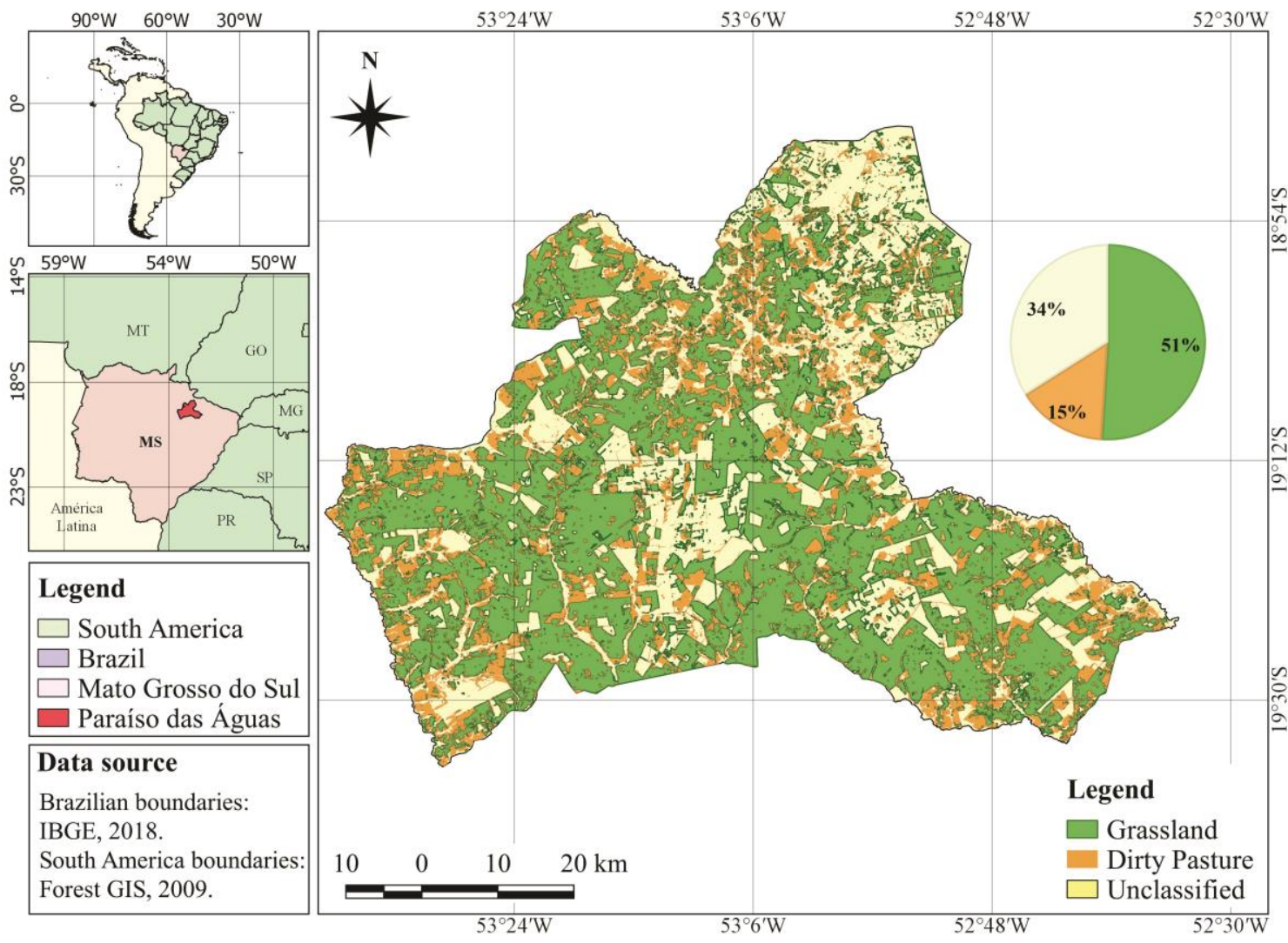

Source - Authors. 


\section{Normalized difference vegetation index (NDVI)}

The results of grassland areas NDVI are presented in Figure 7. Values close to the maximum are shown in white and represent healthy grasslands in general. Other NDVI values - degradated grasslands - are represented in gray scale. The group "unclassified" encompasses other types of coverage (dirty grassland, cerrado, cerradão, agriculture, water, and exposed soil).

Figure 7 - Paraíso das Águas (MS): The NDVI of the grassland area is represented by the gradient between black and white, wherein the white tones indicate a greater presence of biomass and the black tones represent grasslands with some level of degradation. Black represents the minimum value of NDVI for the grassland class, equal to -0.166 , whereas white represents the maximum value, equal to 0695. The class "Unclassified" that encompasses the land covers that are not classified as grassland, is represented in yellow, 2017.
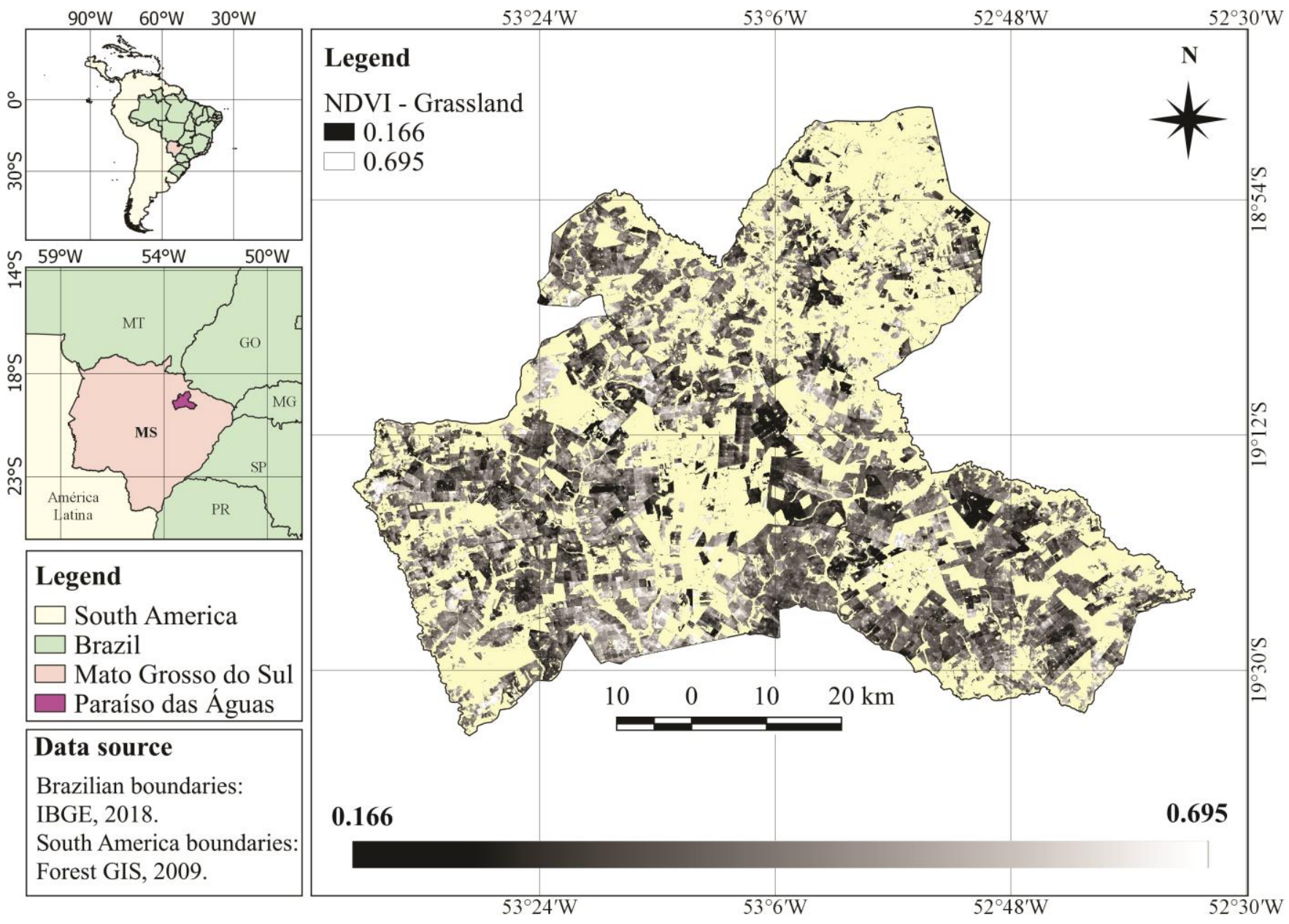

Source - Authors.

Figure 8 highlights the Grasslands sampled polygons in the field over the NDVI. The geographical boundary of Paraíso das Águas is in the lower right corner of the central figure, and polygon 1 (green) is extended with the location of the samples in the municipality, in the center of Figure 8. Based on this polygon, the images identified from $A$ to $K$ are enlarged showing the 40 field samples. 
Figure 8 - Paraíso das Águas (MS): Field samples NDVI. The location of the field samples is represented on the map in the center, where polygon 1 (green) is expanded to show the location of the forty grasslands distributed and listed from $\mathrm{A}$ to $\mathrm{K}$. The rectangles from $\mathrm{A}$ to $\mathrm{K}$ are also expanded on the same spatial scale to improve the visualization. These geographic limits are found over the NDVI derived from the Landsat 8 satellite image OLI sensor, 2017.

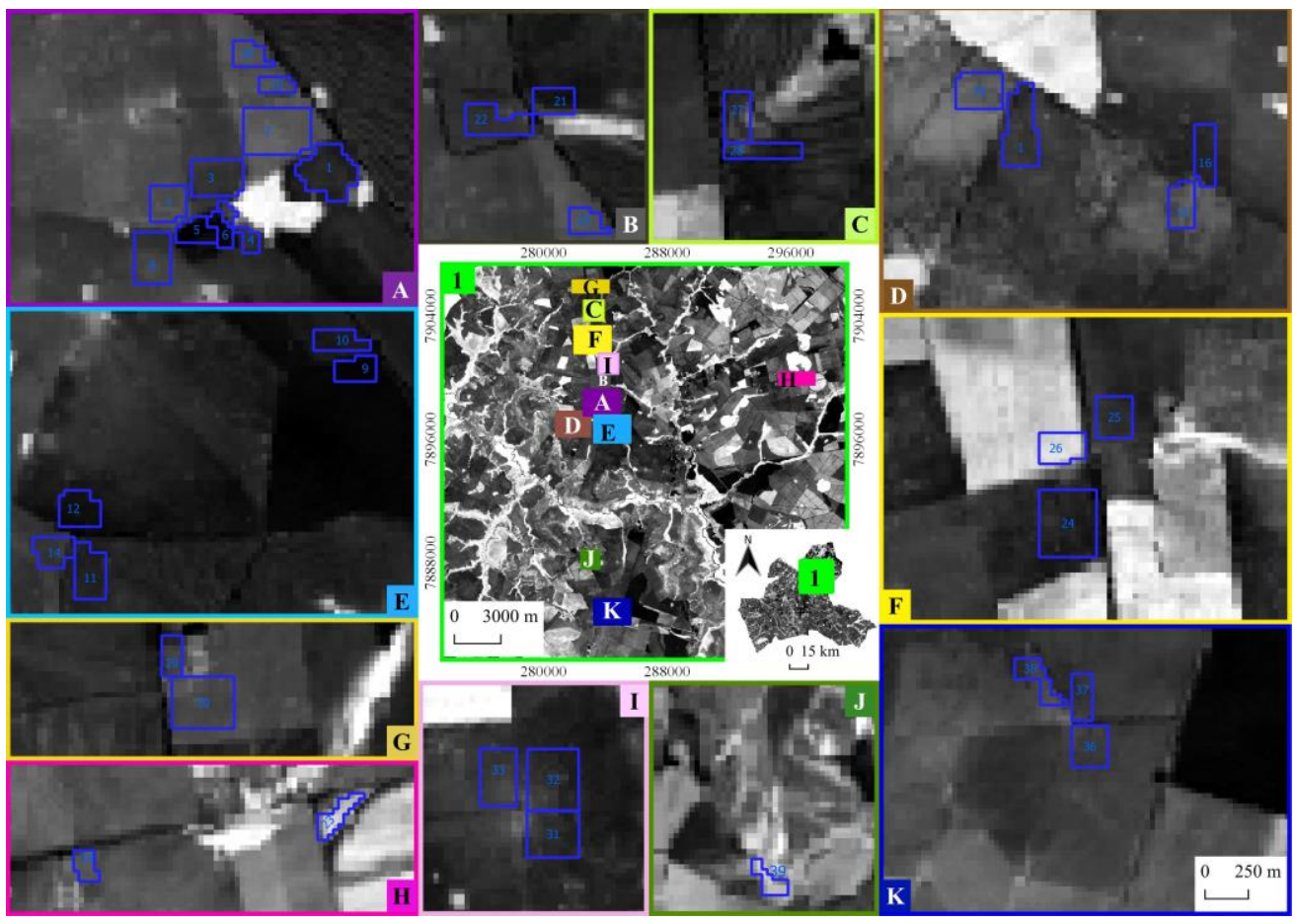

Source - Authors.

Figure 9 shows the frequency of values of the "grassland" class NDVI cells. The average of the NDVI of the Paraíso das Águas - MS grasslands is 0.361 and the standard deviation is 0.054 , with atypical values at its extremes due to the noise of the satellite image classification. The atypical values were disregarded when limiting the NDVI as the Equation 4 and 5.

Figure 8 - Paraíso das Águas (MS): Graph of distribution of NDVI values by the frequency in which they occur in the grassland class in the area. The NDVImean value is 0.3608 , the standard deviation is 0.0539 , the NDVIs value is 0.253 (difference between the mean and double the standard deviation,) and the NDVIV is 0.469 (mean plus twice the standard deviation), 2017.

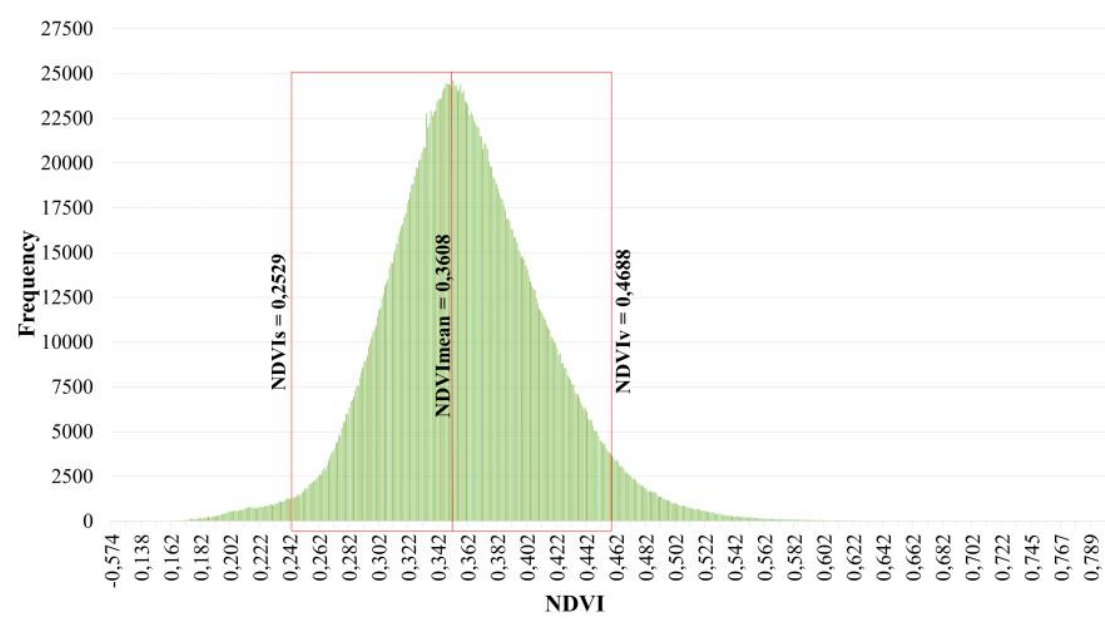

Source - Authors. 
A Box-plot graph was generated using the NDVI values of each of the field samples analyzed to evaluate the amplitude of the standard deviation of each grassland, which represents the heterogeneity of the environment (GAMARRA et al., 2016). Specifically, a relatively high standard deviation and a low mean may indicate the presence of exposed soil and green vegetation in the same sample. Another situation indicative of degradation is when the standard deviation is relatively high and the mean is high due to the presence of invasive plants (GAMARRA et al., 2016). The grassland samples have the following distribution of NDVI values in ascending order of median values.

Figure 10 - Paraíso das Águas (MS): Box-plot graph of NDVI of the 40 specimens of grasslands in ascending order of median values. The marked groups (blue and red) in extremes of the graph confirm visually the results of the GCP, 2017.

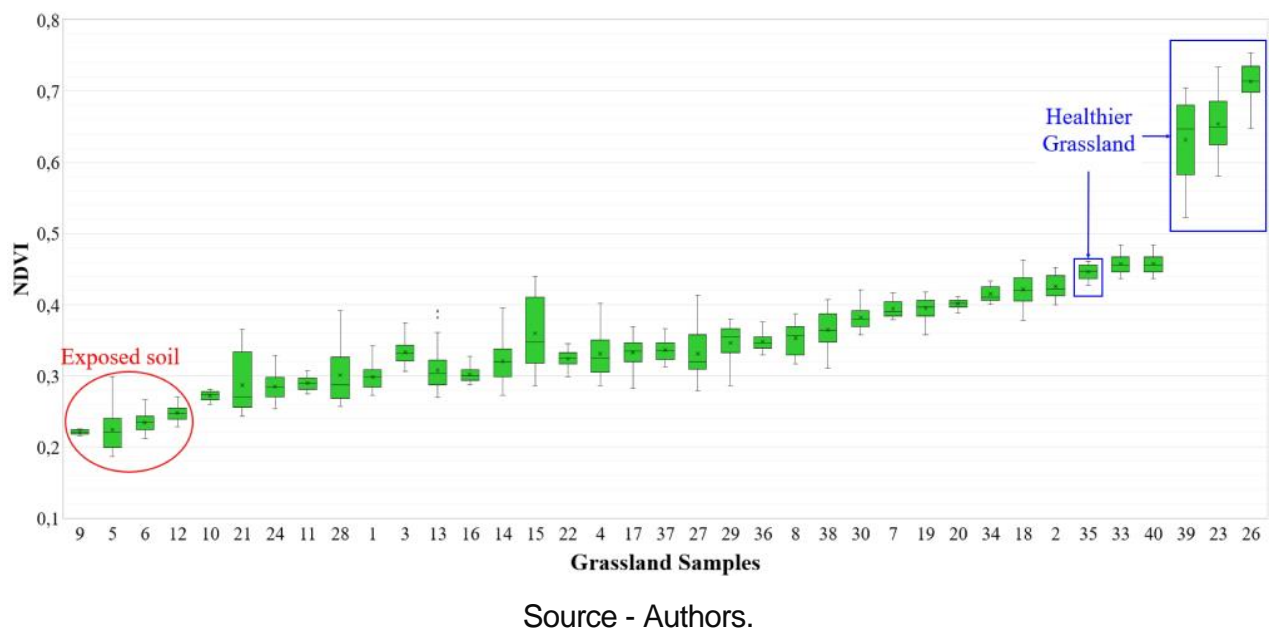

\section{Statistical correlation test}

The analysis of Pearson's linear correlation between the Green Coverage Percentage (GV) obtained using field pictures and the Grassland Vegetation Coverage (GVC) revealed a significant correlation between the two sets of indexes (Figure 11). The correlation coefficient was $79.8 \%$.

Figure 11 - Paraíso das Águas (MS): Linear correlation between Green Coverage Percentage and Grassland Vegetation Coverage Green, 2017.

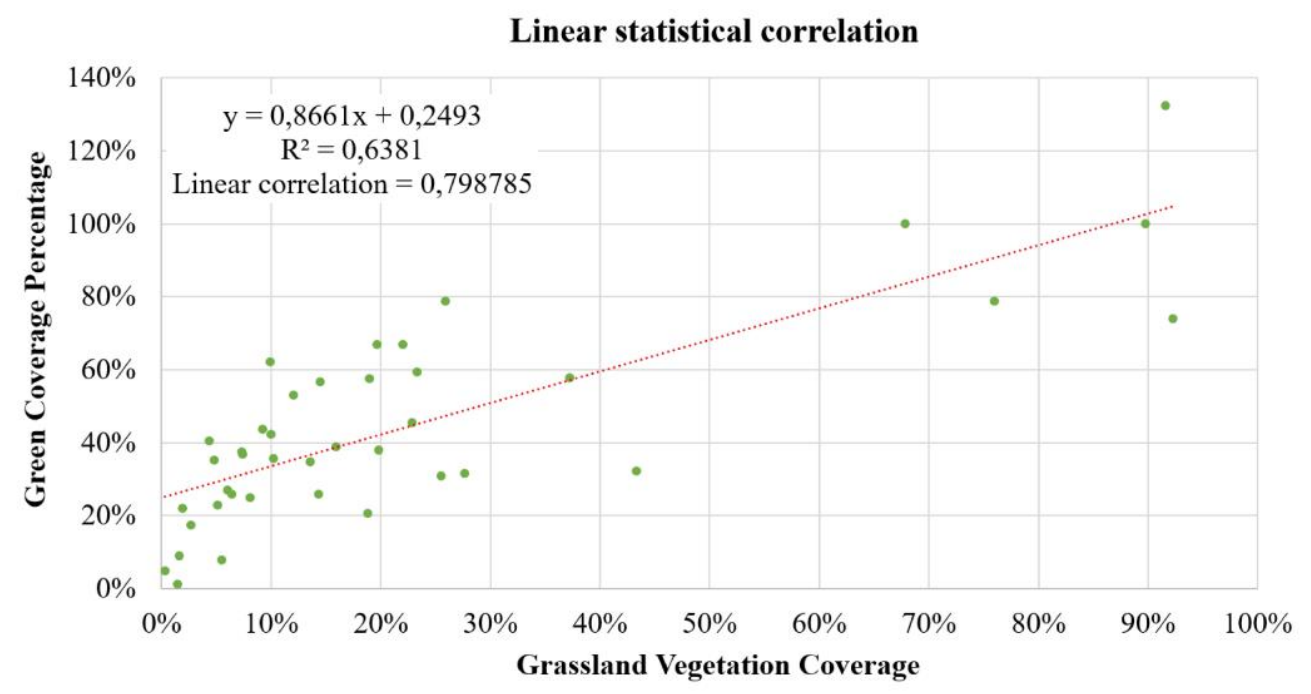

Source - Authors. 


\section{Grassland Degradation in Paraíso das Águas}

Non-degraded grasslands covered an area of $71.9 \mathrm{~km}^{2}$. Slightly degraded grasslands covered an area of $226.3 \mathrm{~km}^{2}$. Moderately degraded grasslands covered an area of $417.0 \mathrm{~km}^{2}$. Finally, severe and extremely severe degraded grasslands accounted for $1269.2 \mathrm{~km}^{2}$ and $466.9 \mathrm{~km}^{2}$, respectively. In addition to the degree of degradation proposed by Gao et al. (2006), grasslands with invasive species were classified as having a distinct degree of degradation called biological degradation, and accounted for an area equal to $2.3 \mathrm{~km}^{2}$. The average GDI of the entire region was $2.49 \%$ of the grassland, corresponding to moderate degradation.

The proportion of grassland degradation is presented in Table 4. It is observed that most of the grassland coverage of the Municipality $(25.22 \%)$ is severely degraded $(\mathrm{GDI}=4)$ and extremely degraded $(9.28 \%)$.

Table 4 - Paraíso das Águas (MS): Proportion of grassland degradation, 2017.

\begin{tabular}{cc}
\hline Degree of grassland degradation & Coverage (\%) \\
\hline ESD grassland & $9.28 \%$ \\
SED grassland & $25.22 \%$ \\
MD grassland & $8.29 \%$ \\
SLD grassland & $4.50 \%$ \\
ND grassland & $1.43 \%$ \\
BD grassland & $0.05 \%$ \\
Unclassified & $51.24 \%$
\end{tabular}

Note: ND - Not Degraded, SLD - Slightly Degraded, MD - Moderately Degraded, SED - Severely Degraded, ESD Extremely Severely Degraded, and BD - Biologically Degraded.

\section{Source - Authors.}

According to the general characteristics of the regional distribution of grassland degradation in Paraíso das Águas in 2017 (Figure 12).

Figure 12 - Paraíso das Águas (MS): Grassland Degradation Map. The legend shows the degree of grassland degradation where $\mathrm{ND}=$ Non-Degraded, $\mathrm{SLD}=$ Slightly Degraded, $\mathrm{MD}=$ Moderately Degraded, $\mathrm{SD}=$ Severe Degraded, $\mathrm{ESD}=$ Extremely Severe Degraded, and BD= Biologically Degraded, 2017.

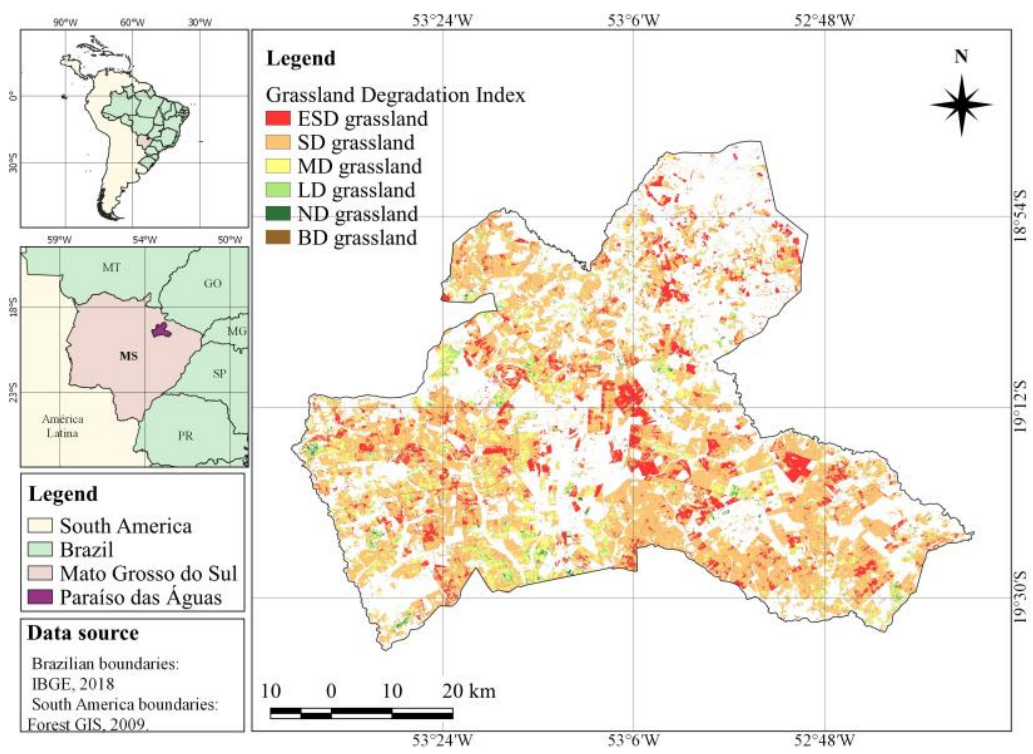

Source - Authors. 
Jaíza Santos Motta

César Claudio Cáceres Encina

Eliane Guaraldo

Analysis of the degree of grassland degradation using

Ariadne Barbosa Gonçalves

remote sensing

Roberto Macedo Gamarra Antonio

Conceição Paranhos Filho

The Figure 13 shows samples classified by GDI. It's observed that most of the grasslands are degraded. Some samples of exposed soil (S5, S6, S9 e S12) stablished as minimum grassland covered are not classified by GDI because they don't have grasslands; also, the exuberant grasslands, uncommon for dry seasons, were not classified (S23, S26, S39, and S40).

The identified brown areas represent biological degraded grassland are not considered by Gao et al. (2006), so they are not included for five level classification.

Figure 13 - Field samples location in Paraíso das Águas is represented on the map in the center, where polygon 1 (green) is expanded to show the location of the forty grasslands distributed and listed from $\mathrm{A}$ to $\mathrm{K}$. The rectangles from $A$ to $\mathrm{K}$ are also expanded on the same spatial scale to improve the visualization. These geographic limits are found over the GDI derived from the GVC, 2017.
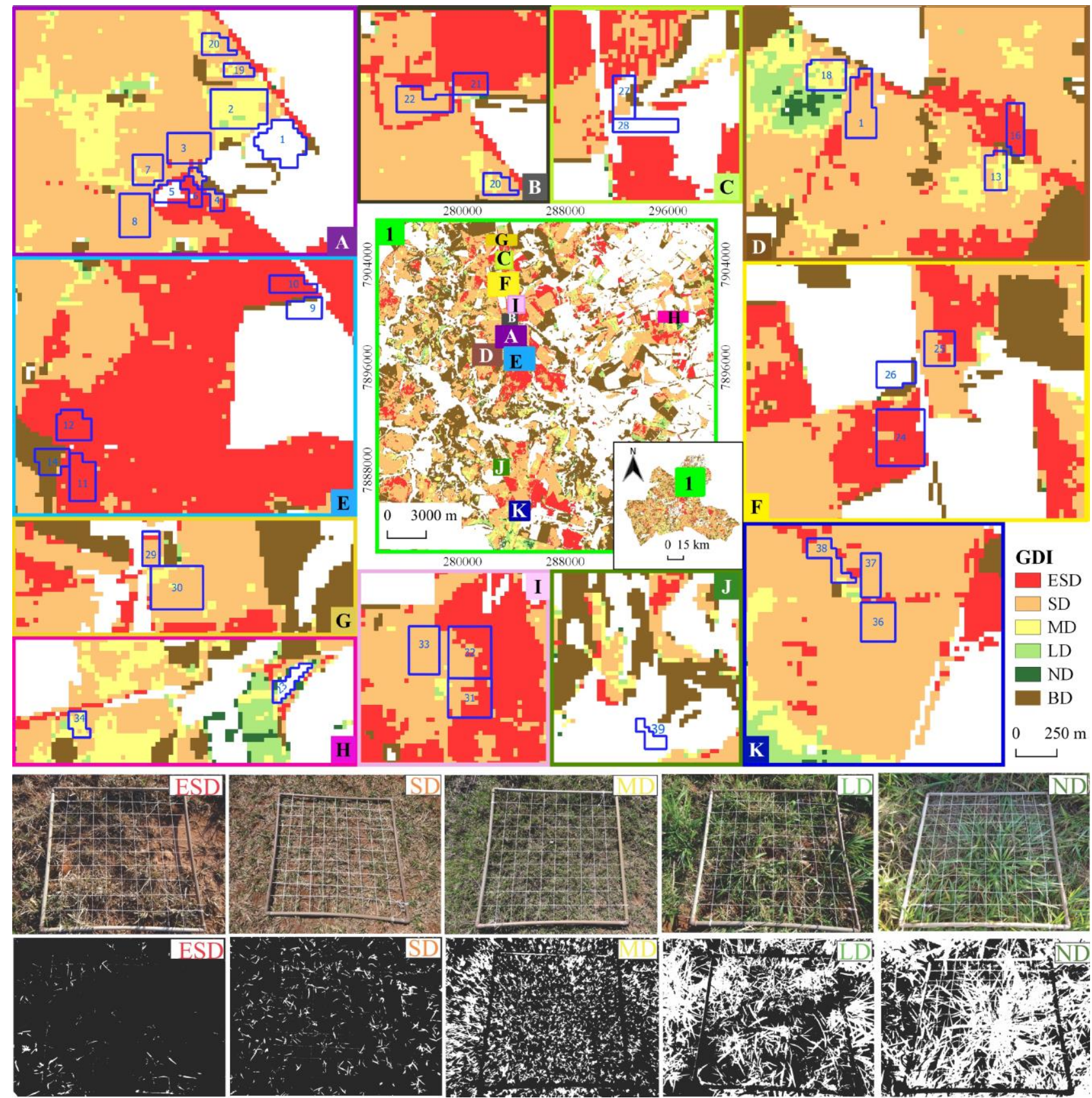

Source - Authors. 

Conceição Paranhos Filho

\section{FINAL CONSIDERATIONS}

The Grassland Degradation Index (GDI) was adapted to non-native grasslands to categorize degradation into five classes using a single satellite image with a spatial resolution of 30 meters. The present study revealed that $9.28 \%$ of the total grasslands in Paraíso das Águas Municipality is "extremely severe degraded"; $25.22 \%$ are "severely degraded"; $8.29 \%$ are "moderately degraded"; $4.50 \%$ are "slightly degraded", and $1.43 \%$ is "non-degraded" grassland.

The objectives of this investigation were achieved, which included adapting the GDI to a single date with a well-defined wet and dry season, characteristic of savanna biome, over multitemporal Gao et al. (2006) Index method. Moreover, the strong correlation between the green coverage percentage (GCP) obtained using the field images and the grassland vegetation coverage (GVC) derived from the satellite image confirm the possibility of using satellite images to effectively identify the degree of grassland degradation.

Since there are limitations in distinguishing between agricultural and healthy grasslands, even in the dry season, the classification of land cover should consider this limitation when using medium spatial resolution satellite imagery.

\section{ACKNOWLEDGMENT}

This work was carried out with support from the Fundação Universidade Federal de Mato Grosso do Sul UFMS/MEC - Brazil. We thank the Postgraduate Program in Natural Resources (Programa de PósGraduação em Recursos Naturais - PGRN - UFMS). And also the support of Fundação de Apoio ao Desenvolvimento de Ensino, Ciência e Tecnologia do MS - FUNDECT for financial support by the Scholarship (Process: 71/700.174/2017). In addition, we also thank the support of Coordenação de Aperfeiçoamento de Pessoal de Nível Superior - Brasil (CAPES) - Financing Code 001, also by the PostDoctorate scholarship. And we also thank CNPq (Conselho Nacional de Desenvolvimento Científico e Tecnológico) to PQ grant (CNPq Process 305013/2018-1).

\section{REFERENCE}

DIAS FILHO, M.B. Silvipastoral Systems in the Recovery of Degraded Tropical Pastures. Symposium Proceedings of the 43rd Annual Meeting of SBZ, João Pessoa - PB, 2006 (in portuguese).

DIAS FILHO, M.B. Pasture Degradation: what it is and how to avoid it. 1. Ed. Embrapa Amazônia Oriental, 2017. 24p (in portuguese).

EMBRAPA. Embrapa maps degradation of Cerrado pastures, 2014. Available at: (https://www.embrapa.br/busca-de-noticias/-/noticia/2361250/embrapa-mapeia-degradacao-daspastagens-do-cerrado). Accessed on: 26 oct. 2019 (in portuguese).

FRANCO, J. B. S.; ROSA, R. Análise da possibilidade de identificar pastagens degradadas utilizando dados radiométricos de campo. Revista Sociedade \& Natureza, v. 16, n. 31, 2004.

GAO, Q.; WAN, Y.; LI, Y.; LIN, E. Grassland degradation in Northern Tibet based on remote sensing data. Journal of Geographical Sciences, v. 16, n. 2, p. 165-173, 2006. https://doi.org/10.1007/s11442-006$\underline{0204-1}$

INSTITUTO BRASILEIRO DE GEOGRAFIA E ESTATÍSTICA - IBGE. Censo Agropecuário 2017. Available in: <https://censoagro2017.ibge.gov.br/templates/censo agro/resultadosagro/index.html>. Accessed in July 2018. 
INSTITUTO BRASILEIRO DE GEOGRAFIA E ESTATÍSTICA - IBGE. PPM 2018: rebanho bovino diminui e produtividade nacional de leite ultrapassa 2 mil litros por animal ao ano, 2019. Available in: < https://agenciadenoticias.ibge.gov.br/agencia-sala-de-imprensa/2013-agencia-de-

noticias/releases/25482-ppm-2018-rebanho-bovino-diminui-e-produtividade-nacional-de-leite-

ultrapassa-2-mil-litros-por-animal-ao-ano>. Accessed in May 2020.

INSTITUTO BRASILEIRO DE GEOGRAFIA E ESTATÍSTICA - IBGE, Limites administrativos do Brasil e de seus municípios, 2018. Available in: < https://www.ibge.gov.br/geociencias/organizacao-doterritorio/estrutura-territorial/15774-malhas.html?=\&t=downloads>. Accessed in May 2020.

GAMARRA, R. M.; TEIXEIRA-GAMARRA, M. C.; CARRIJO, M. G. G.; PARANHOS FILHO, A. C. Use of NDVI in the analysis of vegetation structure and protection effectiveness of the Conservation Unit in the Cerrado. Revista Ra'e Ga Geographic Space in Analysis, vol. 37, p. 307-332, 2016. https://doi.org/10.5380/raega.v37i0.42454

KOPPEN-GEIGER, Climate Classfication. Hydrol. Earth Syst. Sci., 11, 1633-1644, 2007. https://doi.org/10.5194/hess-11-1633-2007

LIU, H.; ZHANG, Y.; ZHANG, X. Monitoring vegetation coverage in Tongren from 2000 to 2016 based on Landsat7 ETM+ and Landsat8. Anais da Academia Brasileira de Ciências, v. 90, n. 3, p. 2721-2730, 2018. https://doi.org/10.1590/0001-3765201820170737

MONTEIRO, E.C.; BURAK, D.L.; CUNHA, A.M.; PASSOS, R.R.; MENDONÇA E.S. Visual assessment of pasture degradation: validation by ground cover and seasonal variation. Revista Ciência Agronômica, v. 49, n. 1, p. 174-182, 2018. https://doi.org/10.5935/1806-6690.20180020

ROUSE, J. W., HAAS, R. H., SCHELL, J. A., \& DEERING, D. W. Monitoring vegetation systems in the Great Plains with ERTS. NASA special publication, v. 351, p. 309, 1974.

PARAíSO DAS ÁGUAS (MS). Town hall, 2017. Available in:< http://www.paraisodasaguas.ms.gov.br/>. Accessed in May 2019.

PEREIRA, O.J.R.; FERREIRA, L.G.; PINHO, F.; BAUMGARTEN L. Assessing Pasture Degradation in the Brazilian Cerrado Based on the Analysis of MODIS NDVI Time-Series. Remote Sensing, v. 10, n. 11, p. 1761, 2018. https://doi.org/10.3390/rs10111761

PUREVDORJ, T.; TATEISHI, R.; ISHIYAMA, T.; Honda, Y. Relationships between percent vegetation cover and vegetation indices. Int. J. Remote Sensing, 19 (18): 3519-3535, 1998. https://doi.org/10.1080/014311698213795

QGIS Development Team (2019). QGIS Geographic Information System. Open Source Geospatial Foundation Project. http://qgis.osgeo.org

TRIMBLE GEOSPATIAL. Definiens eCognition developer. Version 8.9. Munich: Trimble GeoSpatial, 2014.

\section{UNITED STATES GEOLOGICAL SURVEY (USGS). Earth Explorer}

Available in: < https://earthexplorer.usgs.gov/ >. Accessed in July 2018.

ZHOU, W., GANG, C., ZHOU, L., CHEN, Y., LI, J., JU, W., \& ODEH, I. Dynamic of grassland vegetation degradation and its quantitative assessment in the northwest China. Acta Oecologica-International Journal of Ecology, v. 55, p. 86-96, Feb 2014. ISSN 1146-609X. https://doi.org/10.1016/.actao.2013.12.006 
Jaíza Santos Motta

César Claudio Cáceres Encina

Eliane Guaraldo

Analysis of the degree of grassland degradation using

Ariadne Barbosa Gonçalves remote sensing

Roberto Macedo Gamarra Antonio Conceição Paranhos Filho

WORLD ATLAS. The World's Largest Exporters of Beef. Available in: $<$ https://www.worldatlas.com/articles/the-world-s-largest-exporters-of-beef.html>. Accessed in May 2020.

Recebido em: 16/05/2020

Aceito para publicação em: 19/08/2020 